\title{
ASSESSMENT OF TIDE AND WIND EFFECTS ON THE HYDRODYNAMICS AND INTERACTIONS BETWEEN TIJUCAS BAY AND THE ADJACENT CONTINENTAL SHELF, SANTA CATARINA, BRAZIL
}

\author{
Márcio Fabiano de Souza ${ }^{1}$ and Carlos Augusto França Schettini²
}

\begin{abstract}
The importance of understanding coastal processes and their relationships to continental shelves has become increasingly important as coastal areas experience great socio-economic growth. In this context, Tijucas Bay and its interactions with the adjacent continental shelf was a subject of study through the use of a numerical model (MOHID Water Modeling System) for analysis of its hydrodynamics, exchanges of water masses between the bay and the continental shelf and the water's residence time in the bay. Simulations were run for 30 or more days. Boundary conditions for the simulations were tides, constant river discharge $\left(24 \mathrm{~m}^{3} . \mathrm{s}^{-1}\right)$ and winds. Wind time series represented typical conditions in the region, with NE winds $\left(3 \mathrm{~m} \cdot \mathrm{s}^{-1}\right)$ forcing the domain for five days, then turning in the counterclockwise direction for 12 hours until they were oriented in the SE direction $\left(8 \mathrm{~m} . \mathrm{s}^{-1}\right)$, remaining two days in this direction and again turning counterclockwise for 12 hours and ending in the NE direction. Three scenarios have been proposed for the experiment; scenario 1 was forced by tides and river discharge, and scenarios 2 and 3 were forced by tides, river discharge and winds. The difference between scenarios 2 and 3 was the wind direction at the beginning of the simulations: scenario 2 began with NE winds, and scenario 3 began with SE winds. The results showed that the hydrodynamics and water exchange of Tijucas Bay were strongly influenced by tide and wind. The tide provided the input and output water pattern in the bay, while the wind accelerated the process, increasing the speed of exchange between the bay and the adjacent shelf. Superficial layers were the most affected by the winds. The easternmost portion of the bay exhibited the greatest current speeds, with a tendency to form a gyre current with water input at one end and output at the other, depending upon wind direction. In the shallower regions, currents exhibited their greatest speeds, while in the deeper areas, the inverse was found. The residence time for scenario 1 was 75 days, and for scenarios 2 and 3, the residence times were 19 and 15 days, respectively. The hydrodynamics of Tijucas Bay is a sum of processes related to its forcings; however, it is important to highlight the role of winds as one of the major determinants of the dynamics of this region, directly affecting transport throughout the bay.
\end{abstract}

Keywords: circulation, estuary-shelf interaction, residence time.

RESUMO. Atualmente o entendimento de processos costeiros e sua relação com a plataforma continental ganha importância a medida em que as regiões costeira tornam-se áreas de grande expansão sócio-econômica. Neste contexto, a Baía de Tijucas e sua interação com a plataforma adjacente foi alvo de investigação através do uso de modelo numérico (MOHID) para análise da hidrodinâmica, troca de massas de água entre baía e plataforma e tempo de residência da baía. As simulações correram por 30 dias ou mais. As condições de fronteiras para as simulações foram maré, descarga fluvial constante $\left(24 \mathrm{~m}^{3} . \mathrm{s}^{-1}\right)$ e ventos. As séries temporais de ventos representam condições típicas da região com ventos NE $\left(3 \mathrm{~m} . \mathrm{s}^{-1}\right)$ forçando o domínio por 5 dias girando no sentido anti-horário durante 12 horas até a direção SE $\left(8 \mathrm{~m} . \mathrm{s}^{-1}\right)$, permanecendo por 2 dias nesta direção e novamente girando no sentido anti-horário por 12 horas até a direção NE. Três cenários foram propostos para 0 experimento, cenário 1 foi forçado por marés e descarga fluvial, cenários 2 e 3 forçados por marés, descarga fluvial e ventos. A diferença entre os cenários 2 e 3 é a direção do vento no início das simulações, cenário 2 começa com vento NE e cenário 3 com vento SE. Os resultados mostram que a hidrodinâmica e a troca de água da Baía de Tijucas são fortemente influenciadas pela maré e pelo vento. A maré proporciona um padrão de entrada e saída de água da baía, enquanto 0 vento acelera 0 processo aumentando as velocidades de troca entre baía e plataforma adjacente. As camadas superficiais são mais afetadas pelos ventos. As extremidades da baía na sua porção mais a leste apresentam as maiores velocidades das correntes, a tendência é a formação de uma corrente em forma de giro com entrada de água por uma extremidade e saída por outra, dependendo da direção do vento. Nas partes mais rasas as correntes apresentam maiores velocidades enquanto nas partes mais profundas é o inverso. 0 tempo de residência para o cenário 1 foi de 75 dias, enquanto os cenários 2 e 3 apresentaram tempo de residência de 19 e 15 dias, respectivamente. A hidrodinâmica da Baía de Tijucas é um somatório de processos relacionados às suas forçantes. Entretanto é importante destacar o papel dos ventos como um dos principais condicionantes da dinâmica desta região afetando diretamente o transporte baía afora.

\footnotetext{
Palavras-chave: circulação, interação estuário-plataforma, tempo de residência.

1 Universidade Federal do Rio Grande do Sul, Graduate Program in Geosciencees (PPGGeo/UFRGS), 91509-900 Porto Alegre, RS, Brazil

- E-mail: marcio_fsouza@yahoo.com.br

2 Universidade Federal de Pernambuco, Department of Oceanography (Docean/UFPE), Av. Prof. Moraes Rego, 1235, 50670-901 Recife, PE, Brazil

- E-mail: guto.schettini@gmail.com
} 


\section{INTRODUCTION}

The understanding of processes affecting the dynamics of coastal environments, such as hydrodynamics, has gained importance as the scientific community concentrates on understanding ocean processes. In addition, the fact that coastal areas are directly involved in the activities of productive sectors, such as the oil, fisheries and civil engineering industries, as well as port activities makes them key factors in economic development. Therefore, the study of hydrodynamics in coastal environments is critical for the understanding of processes involved in their dynamics.

The study of coastal hydrodynamics comprises a set of analyses, and the dynamics of these environments are directly related to water exchange times. Residence time and other measures used in water renewal analysis have been used as parameters to classify estuaries and semi-enclosed water bodies (Dyer, 1973; Bolin \& Rodhe, 1973; Zimmerman, 1976; Takeoka, 1984). The main goal of using these parameters is to quantify how long water is retained by these water bodies. These time scales can be used as indicators for the analysis of processes such as pollutant transport, sediment transport or ecological processes (Braunschweig et al., 2003). To assess these time scales, one can start from experimental studies using passive tracers (e.g., Deleerrsnijder et al., 2001) or apply Lagrangian transport models (e.g., Oliveira \& Baptista, 1997; Tartinville et al., 1997).

Numerical hydrodynamic models are widely used currently to assess residence times in coastal environments (Signell \& Butman, 1992; Luff \& Pohlmann, 1995). These models are based on the introduction of a hypothetical mass of conservative tracers released instantaneously within an area of interest. The tracer concentration is initially set within the area; the subsequent advection and dispersion of the mass is obtained by numerically solving transport equations, while the tracers are tracked and the variation (or not) of the retention time of the tracers in the area is calculated. The analysis of residence time through numerical models and tracers is often gauged by a reduction of tracer mass to a certain level (such as $50 \%$ or $10 \%$ ) of the initial mass (Choi et al., 2004).

Many hydrodynamic studies using numerical modeling are conducted using a barotropic approximation by averaging the water speed vertically and solving the resulting horizontal twodimensional circulation (2D models). This simplification facilitates the modeling process by minimizing the domain and significantly lowering the computational cost (e.g., Signell \& Butman, 1992; Chen, 1998; Gillibrand, 2001; Wang et al., 2004; Bilgili et al., 2005; Malhadas et al., 2009b). However, improvements in numerical schemes and advances in the processing power of computers are increasingly allowing the employment of models that also solve the water column vertical structure (3D models), which provide a better representation of the circulation (e.g., Andrejev et al., 2004; Garcia, 2008).

Coastal circulation in continental shelf areas and coastal embayments is forced mainly by wind and to a lesser extent by tides and even by river input, if any (Bowden, 1983). Both wind and tides constitute boundary conditions in models: winds are considered to act on an entire domain through the stress at the surface and the tides on horizontal open boundaries and propagating into the domain. Many studies have demonstrated the efficiency of numerical models in the reproduction of coastal circulation forced by wind, including the effects of exchanges with coastal bays and vertical circulation (e.g., Davies, 1982; Davies \& Jones, 1992; Davies \& Hall, 1998; Xie \& Eggleston, 1999; Suzuki \& Matsuyama, 2000).

The present paper aimed to study the circulation of Tijucas Bay, at the State of Santa Catarina (SC), and assessed the tidal and wind roles in the exchange process between the bay and the adjacent continental shelf using a hydrodynamic numerical modeling tool. The study was based on scenario simulations of idealized wind conditions to allow clear decompositions of the phenomena involved. As in most coastal environments, there is a great lack of observational data, and the present study aimed to contribute to understanding of the local oceanography.

\section{STUDY AREA}

Tijucas Bay is located between the $27^{\circ} 10^{\prime}$ and $27^{\circ} 18^{\prime} \mathrm{S}$ parallels (Fig. 1), with an approximate area of $100 \mathrm{~km}^{2}$. Its length and width are nearly equal at $10 \mathrm{~km}$. The Tijucas Bay has as its geographical limits the mouth of the Tijucas River to the west, Zimbros beach to the north, Ganchos beach to the south and an adjacent internal continental shelf to the east. Its proximity to Florianópolis Island makes the bay a fairly sheltered and protected area, mainly with regard to waves from the southern quadrant. The bay is a unique environment on the Southern Brazilian coast, as it is the only one exhibiting a wide intertidal mudflat area, indicating that the bay exhibits a hydrodynamic regime that favors the retention of fine sediments (Buynevich et al., 2005; Schettini et al., 2010).

The coastal plain of Tijucas extends for approximately $5 \mathrm{~km}$ off of the coast, formed mainly by muddy deposits in the form of cheniers, overbank deposits and tidal mudflats (Fitzgerald et al., 2007). Buynevich et al. (2005) state that the bay of the Tijucas River is characterized by a high concentration of suspended material throughout most of the year, mainly due to Tijucas river discharge and the entrapment of tons of fine sediment. This high 


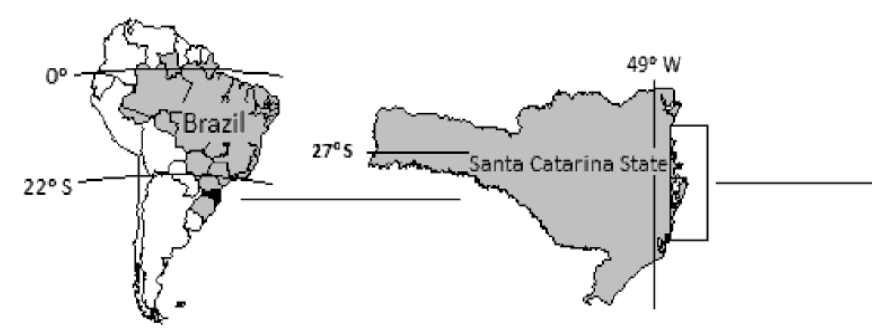

(A)

(B)
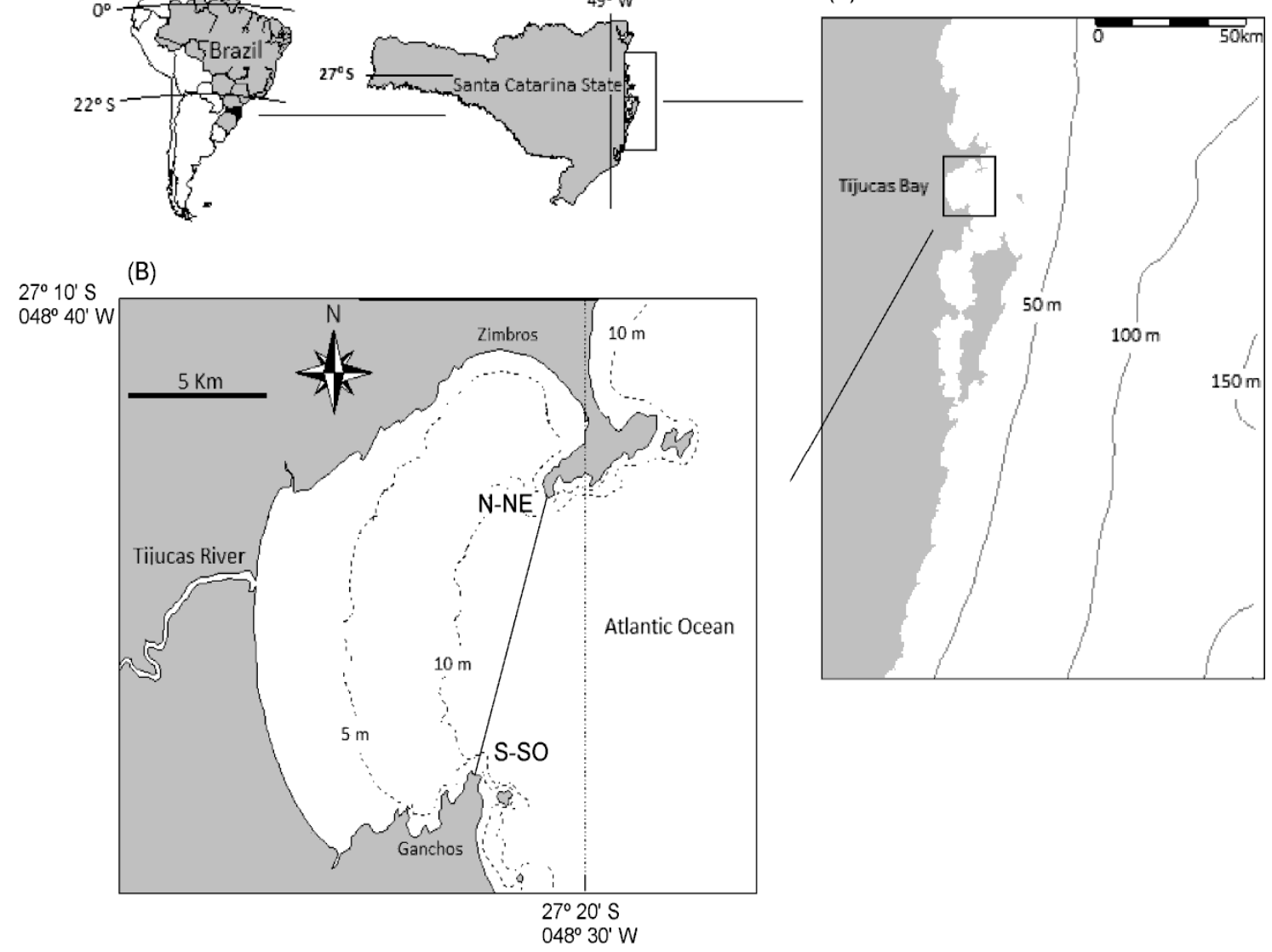

Figure 1 - Study area, Tijucas Bay, central coast north of Santa Catarina, Brazil, father domain (A) and son domain (B). In particular the cross-Section (N-NE/S-SO) delimiting the Tijucas Bay.

sediment input results in a decrease of wave energy in the environment and the consequent formation and deposition of slurry in the sub- and inter-tidal areas of the estuary. Tijucas Bay is a region where mud is entrapped due to its particular physiography; mudflat intertidal areas are formed in this area, despite microtidal conditions and relatively high wave energy (Asp et al., 2005; Buynevich et al., 2005).

The richness of the geomorphological features of the SC coast and the direction of the coastline can represent a complicating factor for the study of coastal oceanographic process such as sea- and estuary-level oscillations and currents of the internal continental shelf movements induced by the atmosphere. Therefore, the assessment of the behavior of local and synoptic winds is essential to understand the factors that control the hydrodynamics and water quality in coastal areas (Trucculo, 2011).

The regional climate is characterized as subtropical mesothermic without a uniform distribution of rainy periods. It displays a positive hydrological balance, with rainfall values of approximately $1,415 \mathrm{~mm}_{\text {.year }}{ }^{-1}$ and an evaporation potential of approximately $900 \mathrm{~mm}_{\text {.year }}{ }^{-1}$. The annual average temperature is $21.4^{\circ} \mathrm{C}$, ranging between $17.3^{\circ} \mathrm{C}$ and $26^{\circ} \mathrm{C}$ in August and February, respectively (Gaplan, 1986).

The wind regime is dominated by northeasterly (NE) winds throughout the year with the occurrence of periods of winds from the southern quadrant associated with cold fronts crossing the coastal region of the State of Santa Catarina (Truccolo et al., 2006). The changes in meteorological conditions observed in the Southern and Southeastern regions of Brazil are usually associated with the passage, formation or intensification of cold fronts typical of mid-latitude weather systems and active on the Brazilian coast in all seasons (Kousky, 1979; Satyamurty et al., 1998). From 1990 to 1999, the passages of cold fronts were identified by the wind turning toward the southerly $(S)$ direction, the persistence of the $S$ wind for at least one day and a drop in air temperature simultaneous with the wind pattern or up to two days later (Rodrigues et al., 2004). Using the days of cold front passage in 
Santa Catarina as reference, one can clearly discern a climatological pattern of progression with cold fronts typically moving from southwest (SW) to northeast. According to Rodrigues et al. (2004), the passage of cold fronts can be observed year-round with little seasonal variation, although with greater frequency during spring, at approximately four per month and with wind speeds that can reach approximately $5 \mathrm{~m} . \mathrm{s}^{-1}$ (measured at $10 \mathrm{~m}$ above the surface). Goulart (1993), analyzing historical data for the city of Florianópolis (SC) (at the Florianópolis airport meteorological station) approximately $30 \mathrm{~km}$ from Tijucas Bay, found wind speeds ranging from 3.4 m.s s $^{-1}$ in May (the month with the lowest average speed) to $4.7 \mathrm{~m} . \mathrm{s}^{-1}$ in October (the month with the highest average speed). The abovementioned author also found a high standard deviation of the data for maximum wind speeds in May and October of $16 \mathrm{~m} . \mathrm{s}^{-1}$ and $27.1 \mathrm{~m} . \mathrm{s}^{-1}$, respectively.

The bay receives river input in an area of approximately $2.800 \mathrm{~km}^{2}$, and the Tijucas River [Rio Tijucas] is the main contributor for water and sediment transport, flowing into the central portion of the bay. Historical data for Tijucas River flow since 1945, gathered at a measuring station administered by the National Water Agency (Agência Nacional de Águas - ANA), reported an average flow of $24.4 \mathrm{~m}^{3} . \mathrm{s}^{-1}$ (Schettini et al., 2010). The estuary of the Tijucas River displays a highly stratified regime (Schettini \& Carvalho, 1998), and its sediment balance is similar to the pattern of other nearby estuaries (e.g., Schettini et al., 2006). The estuary acts as a sediment sink during low discharge periods and an exporter during river discharge peaks (Schettini \& Toldo Jr., 2006).

The region exhibits a mixed microtidal regime with predominance of semi-diurnal tides. The average height of the tide is approximately $0.8 \mathrm{~m}$, ranging from 0.3 to $1.2 \mathrm{~m}$ during neap and spring tides, respectively (Schettini, 2002a). Meteorological effects can influence up to $30 \%$ of the tidal level variation; in events of cold front passages associated with strong winds from the southern quadrant, the level variation can reach one meter (Truccolo et al., 2006).

The wave regime in the study area is still poorly studied. Based on measurements from a wave-rider buoy located $35 \mathrm{~km}$ from Florianópolis Island, Araujo et al. (2003) identified five wave patterns for the island of Santa Catarina consisting of two swells and three types of waves: a southern swell $\left(\theta=162^{\circ}\right)$ with a period of $11.4 \mathrm{~s}$ and $\mathrm{Hs}$ [significant wave height] between 1.25 and $2.0 \mathrm{~m}$, a southeastern swell $\left(\theta=146^{\circ}\right)$ with a period of $14.2 \mathrm{~s}$ and Hs between 1.50 and $2.0 \mathrm{~m}$, eastern waves $\left(\theta=92^{\circ}\right)$ with a period of $8.5 \mathrm{~s}$ and Hs between 0.75 and $1.75 \mathrm{~m}$, northeastern waves $\left(\theta=27^{\circ}\right)$ with an $\mathrm{Hs}>0.75 \mathrm{~m}$ and southern waves $\left(\theta=188^{\circ}\right)$ with a period of $7.7 \mathrm{~s}$ and $\mathrm{Hs}>1.0 \mathrm{~m}$. Swells from the eastern quadrant (northeast, east and southeast) and southern quadrant predominate at the island and that southern quadrant waves can exhibit Hs values above $4 \mathrm{~m}$ (Araujo et al., 2003).

The water characteristics in the bay are influenced by local continental input and by continental shelf water. The continental shelf belongs to the meridional portion of the Southeastern Brazilian Continental Shelf (SBCS) also known as the Santos Basin. The overall circulation on this portion of the shelf is characterized by the Brazil Current (BC) flow of Tropical origin and south direction (Legeckis \& Gordon, 1982; Olson et al., 1998). According to Rezende (2003), the SBCS exhibits (1) coastal water (CW) that is characterized by low salinity values as a result of admixture between continental coastal waters and shelf waters; (2) tropical water (TW) that flows towards the S/SW in the surface layer of the BC between 0 and $200 \mathrm{~m}$ deep and displays low concentrations of nutrients and dissolved oxygen; and (3) South Atlantic central water (SACW), subjacent to the TW, that is also transported to the S/SW by the BC at depths between 200 and $500 \mathrm{~m}$ and is a nutrient-rich water mass, especially with respect to inorganic nutrients, with high concentrations of oxygen and characterized by temperature and salinity below $20^{\circ} \mathrm{C}$ and 36.4 , respectively (Miranda, 1982).

\section{NUMERICAL MODELING}

The MOHID 3D numerical model (http://www.mohid.com/) was used in the present study with the application of complete formulations for three-dimensional finite-difference calculations, the hydrostatic hypothesis and the Boussinesq approximation (Miranda et al., 2000; Martins et al., 2001).

A nested regular grid approach was adopted. The fathermodel employed a greater geographic extension and a coarser grid $(500 \times 500 \mathrm{~m})$ encompassing an area of $150 \times 180 \mathrm{~km}$, from Penha (at $\left.26^{\circ} 50^{\prime} \mathrm{S}\right)$ until Cabo de Santa Marta (28॰36'S), providing boundary conditions for the son-model domain. The latter model covered mainly the bay area, the Tijucas River estuary and the adjacent continental shelf $(20 \times 35.5 \mathrm{~km})$, with $100 \times 100 \mathrm{~m}$ grid resolution. The grid used was the Arakawa $\mathrm{C}$-grid. The fathermodel was run in barotropic mode (2D) in order to save machine time and because we are not interested in baroclinic processes in the shelf. The son-model, on the other hand, was run in the baroclinic mode (3D) since we are interested in possible effects of the gravitational circulations induced by the buoyancy flux caused by the river discharge. The son-model was setup with 18 vertical layers (1-m thick each layers) in Cartesian coordinates. 
The hydrodynamic model was forced at its boundaries by imposing variations in the tidal level considering 14 tidal constituents $\left(M_{2}, S_{2}, K_{1}, K_{2}, N_{2}, 2 N_{2}, O_{1}, Q_{1}, P_{1}, M_{4}, M f, M m\right.$, Mtm and MSqm; FES2004 - Finite Element Solution, Lyard et al., 2006), annual average river discharge generated by the Tijucas River $\left(25 \mathrm{~m}^{3} \cdot \mathrm{s}^{-1}\right)$ and the time series of the synthetic model winds. The wind series were created to reproduce the typical conditions of local synoptic variability (Truccolo, 2011). The predominant wind regime is $\mathrm{NE}$, which is disturbed by the passage of frontal systems that rotate the wind to southeast. During the passage of cold fronts, intensification of winds also occurs, and after a few days, the winds rotate back to northeast. This cycle displays a temporal variation of 6 to 11 days (Stech \& Lorenzetti, 1992).

The simulations were performed considering three scenarios: a simulation forced only by tide and river discharge and two simulations forced by tide, river discharge and winds, with the latter varying in different patterns (Table 1). The wind series was generated starting with NE winds at $3 \mathrm{~m} \cdot \mathrm{s}^{-1}$ speed, remaining constant for five days and then rotating in a counterclockwise direction to the SE during 12 hours and increasing gradually in speed up to $8 \mathrm{~m} . \mathrm{s}^{-1}$, remaining in this condition for two days and again rotating counterclockwise back to the northeast over 12 hours, with a gradual reduction in speed until the initial conditions were reached (Fig. 2). The difference between scenarios 2 and 3 was the wind direction in the beginning of the simulations: in scenario 2, the wind at the start of the simulation came from a NE direction, and in scenario 3 , the wind at the start of the simulation came from the SE, with a 3-day difference in the phase of the tidal variation. All simulations started during flood tide approximately five days before the spring tidal peak. Previous assessments indicated that this is a satisfactory period for the beginning of the model. Simulations were performed for a 30-day period.

Table 1 - Summary of the boundary conditions of the three scenarios assessed.

\begin{tabular}{|c|c|c|c|}
\hline Scenario & River Discharge & Tides & Wind \\
\hline 1 & Yes $\left(25 \mathrm{~m}^{3} . \mathrm{s}^{-1}\right)$ & Yes & No \\
2 & Yes $\left(25 \mathrm{~m}^{3} . \mathrm{s}^{-1}\right)$ & Yes & Yes (starting NE) \\
3 & Yes $\left(25 \mathrm{~m}^{3} . \mathrm{s}^{-1}\right)$ & Yes & Yes (starting SE) \\
\hline
\end{tabular}

The data analyzed to assess the water exchange between Tijucas Bay and the adjacent internal continental shelf were extracted from the cross-section of the bay, traced along the bay's two eastern ends, near the shelf; the northern end was Zimbros Point (Ponta de Zimbros) (N-NE), and the southern end was Ganchos Point (Ponta de Ganchos) (S-SW; Fig. 1). The crosssectional profile shows depth varying from $7 \mathrm{~m}$ in the swallower areas to $12 \mathrm{~m}$ in the deeper ones, at the points and in the middle of the bay, respectively.

The residence time analysis followed the methodology proposed by Braunschweig et al. (2003), with the hydrodynamic model and Lagrangian transport using tracers and a box. The tracers released inside the box were tracked and residence time of the water enclosed by the box corresponds to the time when $80 \%$ of the tracers were outside of the box. According to Braunschweig et al. (2003), this method is used for two purposes: to release Lagrangian tracers and monitor the passage of these tracers across the box. By monitoring the tracer movements, one can answer some questions regarding the area's hydrodynamics, such as the following: (1) in which is the direction water displaced under certain conditions (forcings); (2) where do the tracers move when released in a certain area inside the box; and (3) what is the input and output of water from the box?

The model was validated by the comparison between the calculated water level from available tidal harmonic constituents at Arvoredo Island, and the modeled water level generated by the tide propagation from the boundaries, at the same location. To objectively assess the model skillness (Sk) to reproduce the observations, we applied an error analysis (Eq. 1) calculated by:

$$
S k=1-\frac{\sum\left|X_{M}-X_{O}\right|^{2}}{\sum\left(\left|X_{M}-\overline{X_{O}}\right|+\left|X_{O}-\overline{X_{O}}\right|\right)^{2}}
$$

where $X_{M}$ represents the instantaneous result of the model, $X_{O}$ represents a synoptic observation for this result and $\overline{X_{O}}$ is the average observed value (Willmott et al., 1985). In the case of perfect ability to reproduce the observation, $S k$ takes a value of 1 , while in the case of a total lack of ability to reproduce the observation, $S k$ is zero. In the present study, $S k$ was 0.96 . This value is not a percentage but an indicator of agreement. The $S k$ value for the present study allows the validation of the model, and for the tidal amplitudes analyzed, the error was below 10\% (Fig. 3).

\section{RESULTS}

Figure 4 shows the depth-averaged current across the bay mouth over time for the three simulated scenarios. By definition, we assigned the currents flowing outside the bay as positive, and those flowing towards the inside the bay as negative. In scenario 1 , forced only by the tides and river discharge, the maximum speeds of currents towards the inside and outside of the bay were $0.13 \mathrm{~m} . \mathrm{s}^{-1}$ and $0.11 \mathrm{~m} . \mathrm{s}^{-1}$, respectively, for currents during spring tide. The greatest speeds occurred near the section ends. The displacement pattern of water masses in both directions followed the tidal cycle, with water masses entering and leaving the 

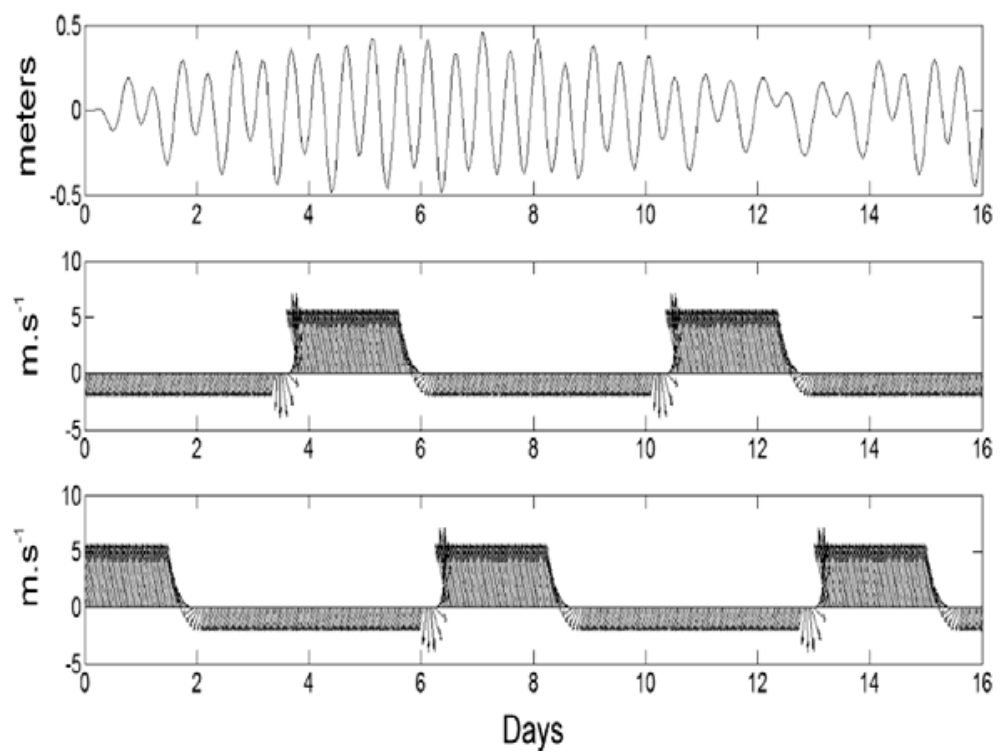

Figure 2 - Time series of water level (upper panel) and wind (lowers panels) used in the simulations with wind.

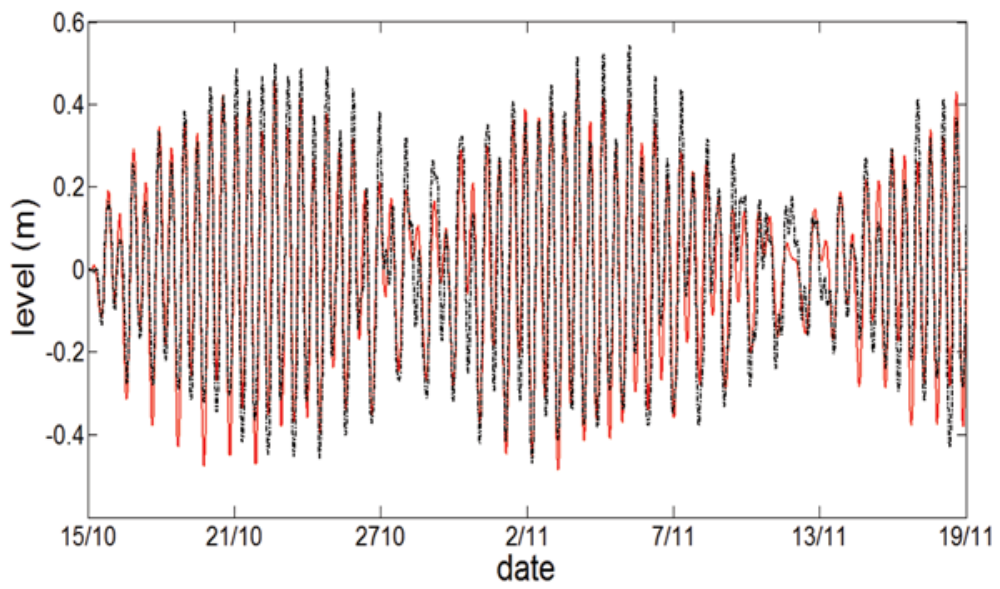

Figure 3 - Comparison between the modeled water level (red) and predicted water level (dashed black) based on harmonic constituents at Arvoredo Island.

bay every six hours, homogeneously over the entire section. During the neap tide period, water masses moved slower, with a speed of approximately $0.05 \mathrm{~m} \cdot \mathrm{s}^{-1}$ in both directions.

In scenario 2, there was a wind effect in addition to the tide and the river discharge, starting with a NE-wind direction. The greatest current speeds were found during the period that coincided with a SE-wind and spring tide. In the period between 100 and 150 hours of the simulation occurred a pattern of inflow current in the southern portion of the bay mouth and outflow currents in the northern bay mouth. The maximum current speed of both sides was approximately $0.18 \mathrm{~m} . \mathrm{s}^{-1}$; however, there was also an oscillation of currents according to the tidal phase. In the neap tide period, during the time interval between 270 and 320 hours of simulation and during the second event of SE-wind, the same current pattern was repeated; nevertheless, the speeds were lower, at approximately $0.10 \mathrm{~m} \cdot \mathrm{s}^{-1}$. During NE-wind, there was a decrease in current intensity and a reversal of predominance in current direction on each side of the bay mouth. During these periods, the maximum current speeds were approximately $0.06 \mathrm{~m} \cdot \mathrm{s}^{-1}$.

Scenario 3 was similar to 2, with differences in the occurrence of wind reversal and the starting point with a SE-wind. The maximum current speed reached approximately $0.16 \mathrm{~m} . \mathrm{s}^{-1}$ 


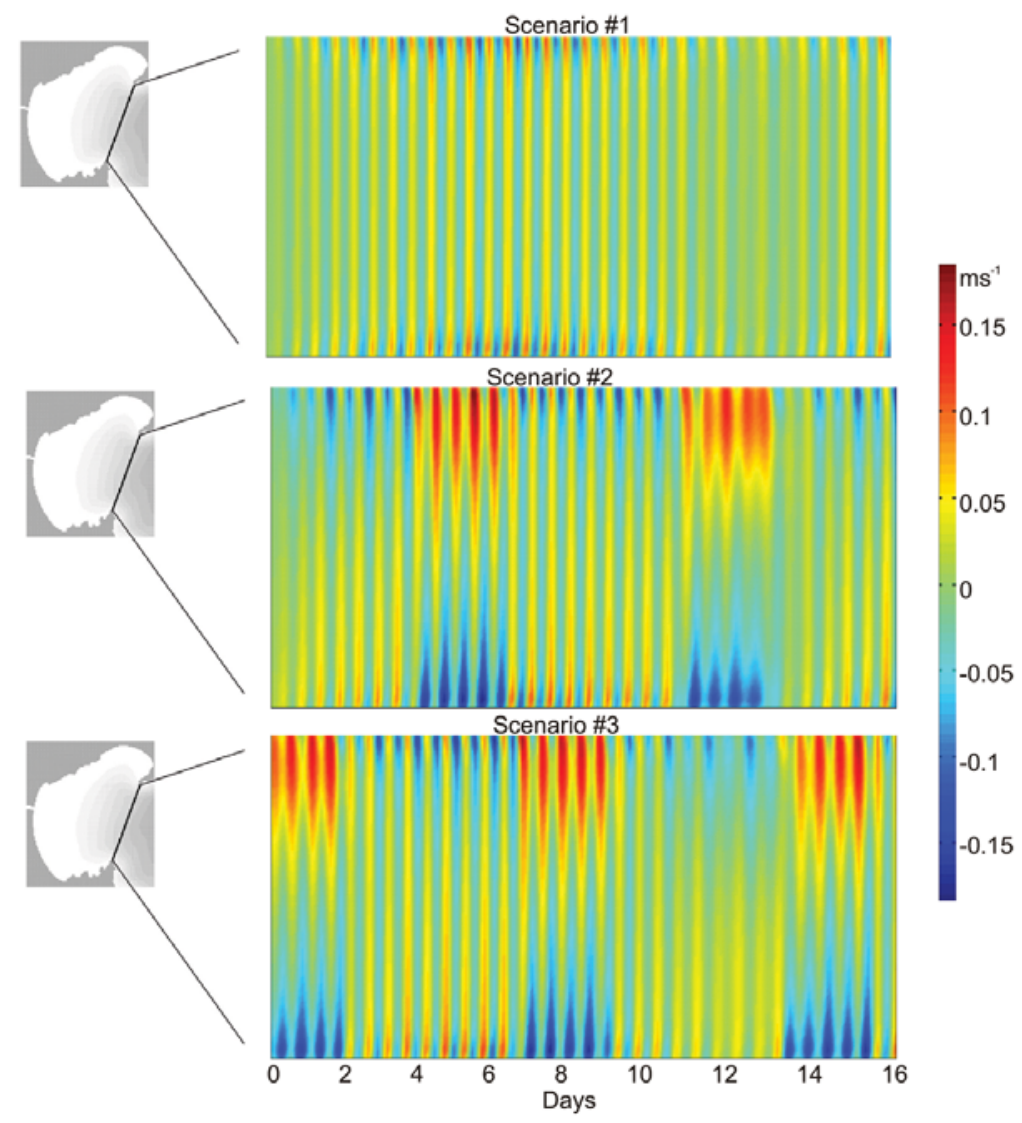

Figure 4 - Depth averaged currents across the bay mouth. Scenario 1: tides and no wind; scenario 2: tides and winds starting with NE-wind; and scenario 3: tides and winds starting with SE-wind. Positive means flow getting in the bay; negative means flow getting out the bay.

during SE-winds. Between 100 and 150 hours of simulation, a period of spring tide and NE-wind, current speeds were approximately $0.10 \mathrm{~m} . \mathrm{s}^{-1}$ and were lower compared with the same period in scenario 2. During the neap tide period, in the time interval between 270 and 320 hours of simulation, the same pattern of currents found during spring tide was also observed, although with lower speeds of approximately $0.05 \mathrm{~m} . \mathrm{s}^{-1}$ in both directions.

Figures 5, 6, 7 and 8 show currents orthogonal to the crosssection of the bay mouth. Instantaneous currents are shown for the flood and ebb periods in the neap and spring tide conditions for the three scenarios. The greatest current speeds occurred at the ends and in the surface layers, mainly when wind was forcing the model. Current surface speeds reached their greatest values, up to $0.50 \mathrm{~m} . \mathrm{s}^{-1}$, both for inflow and outflow currents from the bay, when a SE-wind coincided with spring tide (Fig. 5). In Figure 6, current speeds reached their maximum values of approximately $0.35 \mathrm{~m} . \mathrm{s}^{-1}$ when SE-wind forced the domain; however, this speed was observed at the northern end, indicating outflow from the bay, even at neap tide. Figures 7 and 8 show periods of flood and ebb during neap tide. The currents exhibited speeds below $0.12 \mathrm{~m} . \mathrm{s}^{-1}$ and the same speed distribution pattern in the cross-section.

The distribution of depth averaged residual currents after time-averaging over 25 hours and extreme flood and ebb currents in the spring and neap tide periods are shown in Figures 9 and 10, respectively. During spring tide (Fig. 9), the residual speeds showed variations according to the winds. In scenario 1 , with no wind, the residual speed was virtually zero and the speeds of the flood and ebb tides were equal and opposite. In scenario 2, the residual circulation shows a large clockwise gyre in the bay main body and a smaller eddy in the uppermost region at Zimbros peninsula. In scenario 3 , the residual circulation is anti-clockwise and the there is not the formation of the eddy as occurred in scenario 2; the water entered from the S-SW end and exited in the $\mathrm{N}-\mathrm{NE}$ end. The flood and ebb currents responded to the action of their forcings: in scenario 1, flood and ebb currents were similar but opposite; in scenario 2, flood currents characterized the water inflow into the bay at the N-NE end, while ebb current characterized the water outflow at the S-SW end. Opposite patterns were 
found for flood and ebb currents in scenario 3, in which flood currents entered the bay at the S-SW end and exited at the N-NE end. It is worth noting the highest speeds that the ebb current reached within the bay. Figure 10 shows the neap tide period, in which one can note that scenarios 1, 2 and 3 showed behavior similar to the spring tide period; however, scenarios 2 and 3 displayed higher residual speeds compared to the same scenarios during spring tide.
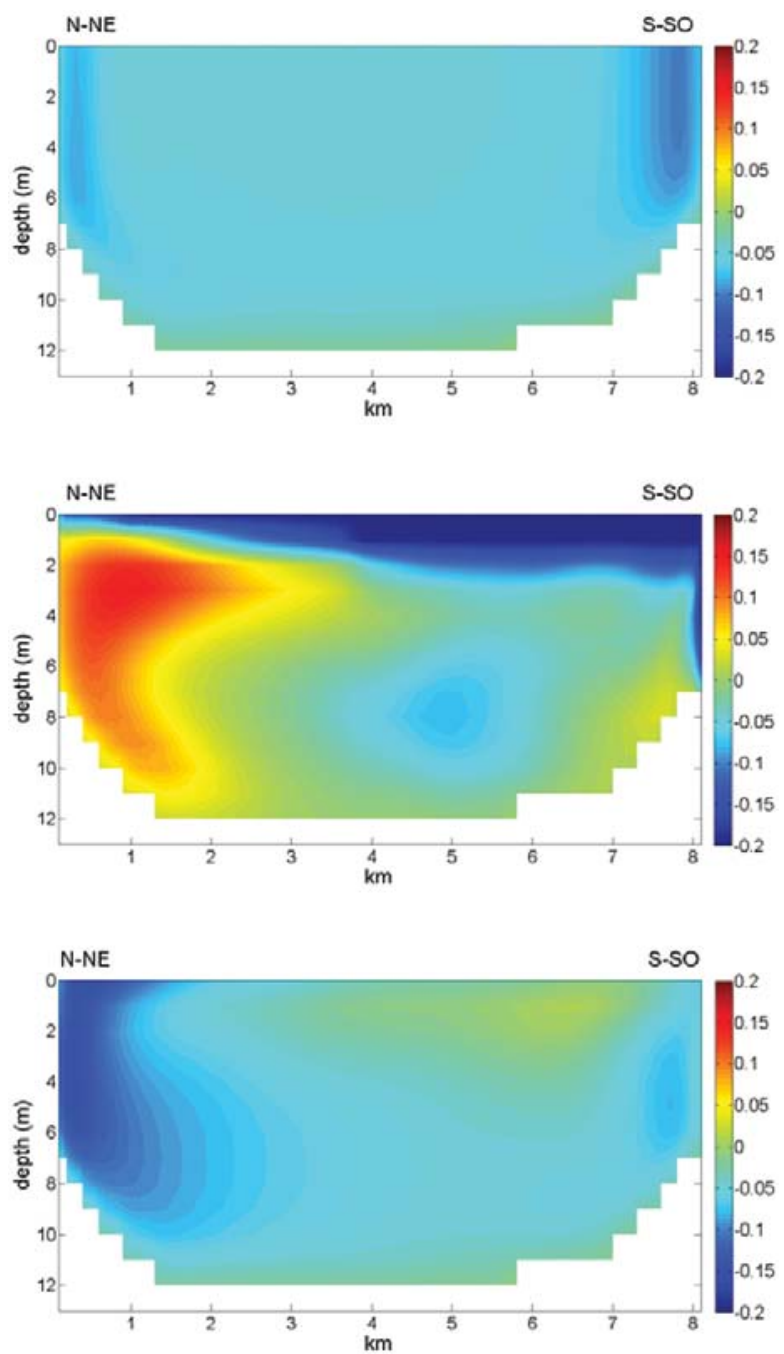

Figure $\mathbf{5}$ - Cross-sectional current velocity $\left(\mathrm{ms}^{-1}\right)$ across the bay mouth at spring tide flood. Top panel: tides and no wind; mid panel: tides and winds starting with NE-wind; and bottom panel: tides and winds starting with SE-wind. Positive means flow getting in the bay; negative means flow getting out the bay.

The residence time for scenarios 1, 2 and 3 were 75, 19 and 15 days, respectively. Figure 11 shows the distribution of tracers in each scenario. In scenario 1, there was a homogenous distribution throughout the domain, with motion in both south and north directions towards the outside of the bay with a very slow disper- sion. The distributions of tracers in scenarios 2 and 3 were similar, with dispersion predominantly towards the north direction.
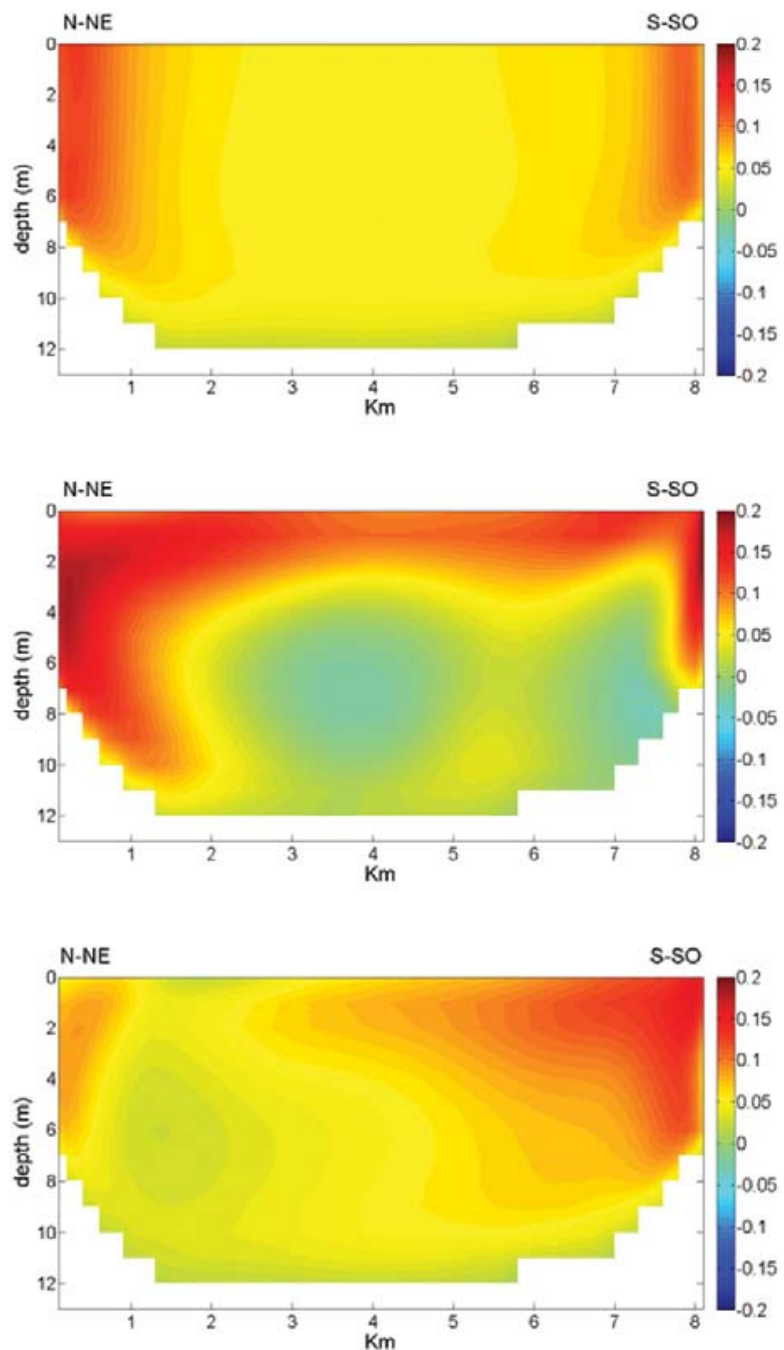

Figure 6 - Cross-sectional current velocity $\left(\mathrm{ms}^{-1}\right)$ across the bay mouth at spring tide ebb. Top panel: tides and no wind; mid panel: tides and winds starting with NE-wind; and bottom panel: tides and winds starting with SE-wind. Positive means flow getting in the bay; negative means flow getting out the bay.

\section{DISCUSSION}

The hydrodynamics of Tijucas Bay are basically the sum of several oceanographic and meteorological forcings on local and regional levels. The major local forcings are currents generated by wind and tide, and when strong winds coincide with spring tide, a greater than usual water exchange between the bay and continental shelf can occur. However, the opposite may also occur because water can be piled up against the coast, a condition that is related to SE winds, and can increase the water residence time inside the bay, decreasing the exchange with the continental shelf. 

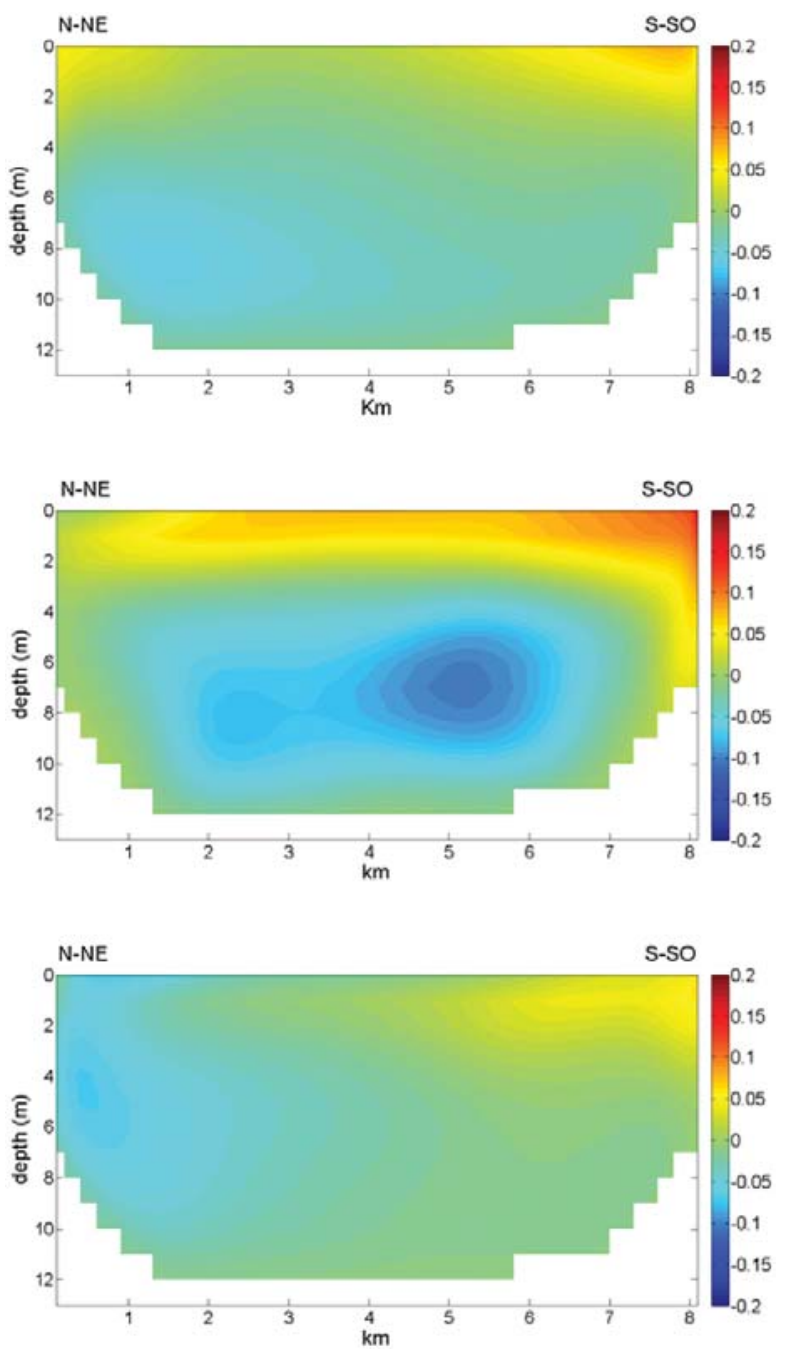

Figure 7 - Cross-sectional current velocity $\left(\mathrm{ms}^{-1}\right)$ across the bay mouth at neap tide flood. Top panel: tides and no wind; mid panel: tides and winds starting with NE-wind; and bottom panel: tides and winds starting with SE-wind. Positive means flow getting in the bay; negative means flow getting out the bay.

The circulation in the continental shelf region, including its innermost portion where bays and coves are located, is directly influenced by the energy transferred by the winds. The circulation pattern of the bays can directly respond to tidal variation (flood and ebb) and, mainly, to the intensity and direction of the winds. In the study area, the winds act as an intensifier of water movement, with the circulation and water exchange being accelerated according to the wind speed. The most frequent wind directions in Tijucas Bay are NE and SE, and the speed of the SE-wind is generally higher compared to the NE-wind, although the NE-wind is the most frequent one. Analyzing the residual speeds, one can note a greater influence of the SE-wind on water exchange and transport during neap tide, while during the spring tide, the exchange is lower. The circulation in the study area is more affected by SE-winds because they frequently display higher speeds and thus transfer more energy to the water column and produce faster currents. In the neap tide period, the wind has more influence on the displacement of currents. Using the indicator vectors of flood and ebb speeds and, mainly, the residual speed, it was found that the SE-wind has an essential role in the final transport towards the outside of the bay. When highlighting the importance of winds in the transport of water mass, it was noted that the difference between scenarios is the coincidence of the SE-wind forcing the domain during neap tide and providing greater transport. The wind effect on the hydrodynamics is primarily shown by the gyre circulation pattern within Tijucas Bay. There is a gyre circulation in the clockwise direction that is noted when the SE-wind forces the domain, while a counterclockwise gyre is noted when the NEwind forces the domain. In these gyres, the speeds tend to be lower in the center of the bay, which is a deeper area. The results of numerical models applied to the Chesapeake Bay using wind and river discharges have shown the influence of these forcings on its hydrodynamics, and the effect produced by the sum of these forcings is responsible for water mass exchanges and transport of both salt and sediments (North et al., 2004). De Castro et al. (2003) found a strong influence of winds in water exchange and transport between Ría de Ferrol (Spain) and the continental shelf. According to the abovementioned authors, the exchanges depend directly on the intensities of local winds, and residence times are essentially controlled by wind regimes. In a study of Armação de Itapocoroy Bay, approximately $100 \mathrm{~km}$ to the north of Tijucas Bay, Schettini et al. (1999) found that the displacement of currents follows the wind more directly than the tidal regime and can usually reach speeds below $0.1 \mathrm{~m} . \mathrm{s}^{-1}$.

The tide directly influences the pattern of water exchange between Tijucas Bay and the adjacent continental shelf. The water input and output to the bay is a response to the tidal diurnal cycle, and every six hours, the flood and ebb tides set the direction of displacement and transport.

By analyzing the residence time, one can clearly note the influence of the wind on the hydrodynamics of the bay. The variation in wind patterns, shifting from NE to SE and vice-versa, often tends to retain the water for a longer period within the bay because the NE-wind generates a current that outflows by the $\mathrm{S}$ portion of the bay, while the SE-wind has an opposite effect. This shift in current direction during a short period of time tends to retain the water for longer within the bay. Residence time seems to be inversely proportional to wind strength. Thus, one can expect variations according to climatic and meteorological conditions because during periods of high energy, strong winds and waves 

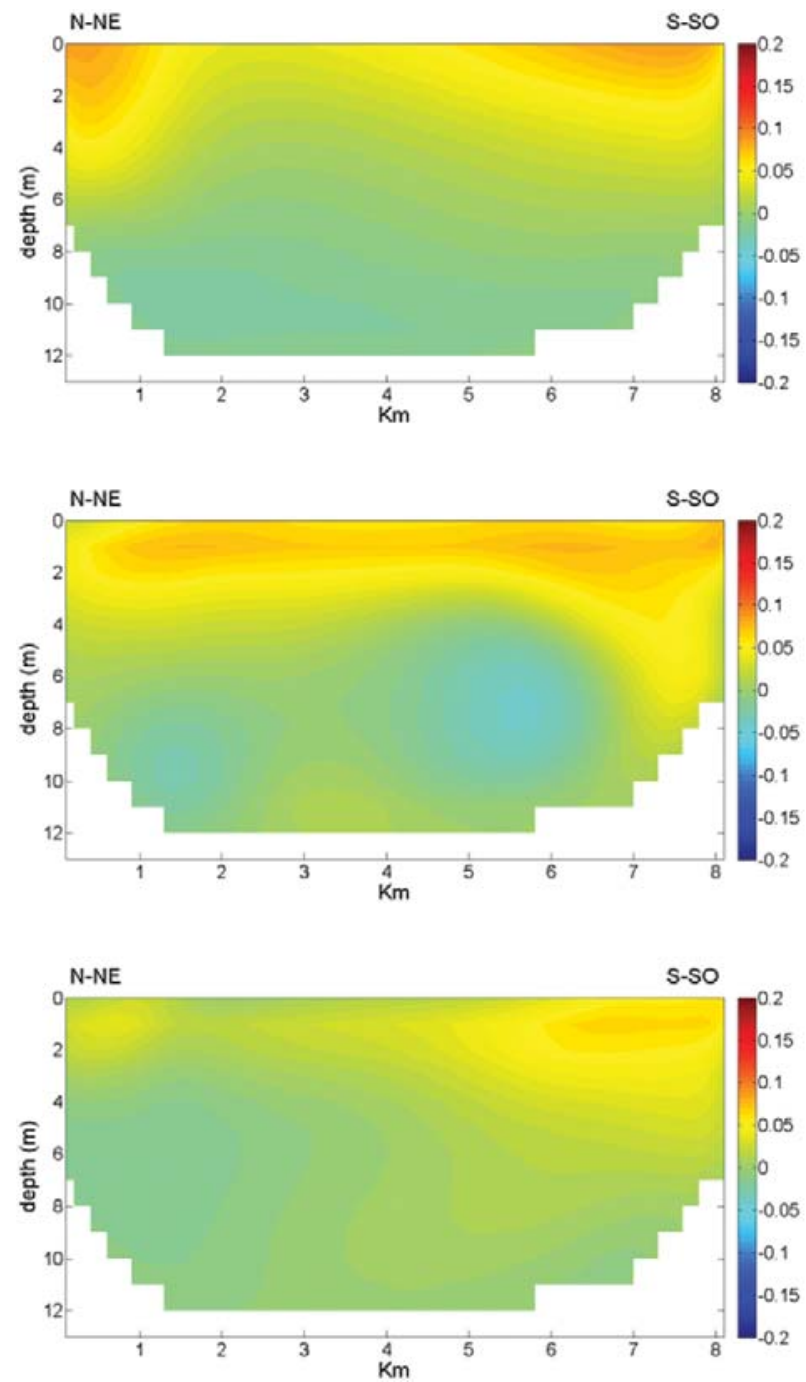

Figure 8 - Cross-sectional current velocity $\left(\mathrm{ms}^{-1}\right)$ across the bay mouth at neap tide ebb. Top panel: tides and no wind; mid panel: tides and winds starting with NE-wind; and bottom panel: tides and winds starting with SE-wind. Positive means flow getting in the bay; negative means flow getting out the bay.

and meteorological tides, the residence time tends to be shorter. Nevertheless, the hydrodynamics become even more complex if other variables are considered, even the meteorological tide that is associated with strong winds from the southern quadrant can act as a brake on the exchange flow.

In accordance with the hydrodynamic characteristics of Tijucas Bay, the exchanges and transport between the bay and the continental shelf are low over time. Short time periods related to cold front passages and strong SE winds can affect this pattern associated with calm water, increasing the exchanges. This fact can be observed in the low speeds produced by tides and winds most of the time.
Geomorphological, meteorological and oceanographic characteristics should be considered and consequently, the transport in coastal regions, especially coves, bays and estuaries, when water exchange is analyzed. Depending on the characteristics, different forcings can assume the main role in coastal hydrodynamics. Braunschweig et al. (2003) found no significant difference in residence time in numerical situations applied to the Tagus estuary (Portugal) when comparing scenarios with no wind and with constant $S$ wind $\left(10 \mathrm{~m} \cdot \mathrm{s}^{-1}\right)$. Malhadas et al. (2010), in a study to assess the residence time of Laguna de Óbidos [Óbidos Lagoon] (Portugal), found that the semi-diurnal tide was the main hydrodynamic forcing, followed by waves. Wang et al. (2004) 

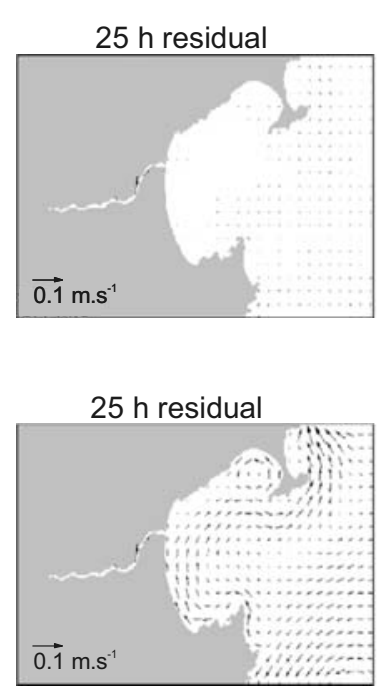

$25 \mathrm{~h}$ residual

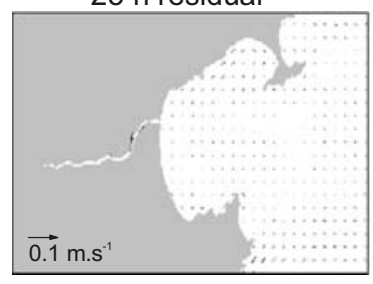

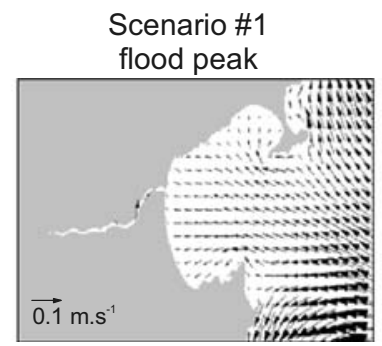

Scenario \#2

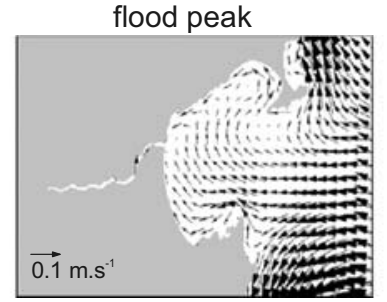

Scenario \#3

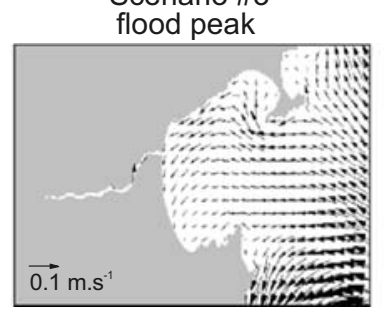

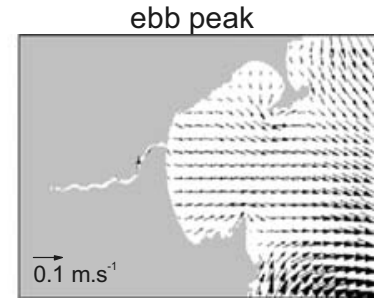

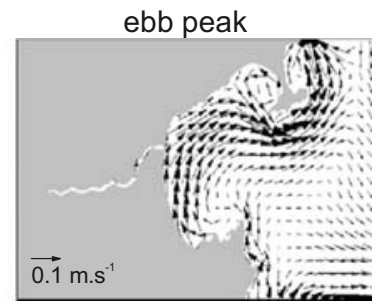

ebb peak

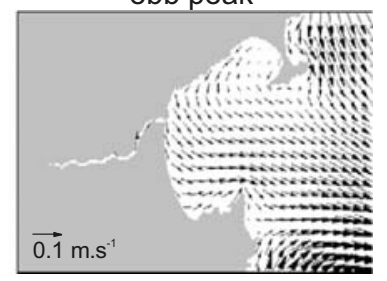

Figure 9 - 25-hours residual currents and flood and ebb peak currents for the three scenarios in spring tide. Scenario \#1: tide and river discharge; scenario \#2: tide, river discharge and wind (SE); and scenario \#3: tide, river discharge and wind (NE).

found for the estuary of Danshuei (Taiwan) that the tide was responsible for approximately $50 \%$ of estuary outflow transport.

The morphology of Tijucas Bay can be another factor influencing water renewal, as the narrowing of the eastern portion of the bay where there is a connection with the adjacent continental shelf may somehow affect the water exchange between the bay and the shelf. Another factor is its proximity to Florianópolis Island, which shelters part of the bay from undertows from the S/SE.

There are indicators of the calm water hydrodynamic pattern during most of the time in the study area. Occasionally, extreme, short events of high energy with strong winds, high river discharge and waves can generate greater current movements within the bay, but sediment characteristics, such as the presence of fine sediments highlighted by some authors, show this pattern of calm waters.

\section{CONCLUSION}

Tijucas Bay is located in a sheltered area and displays characteristics of an environment of calm water hydrodynamics. The microtidal regime acts directly in the current displacement direction towards the inside or outside of the bay according to the cycle period. The wind patterns found in the study region are NE winds, which are more frequent and less intense, and SE winds, which are less frequent and more intense. The transport of water masses between the bay and the adjacent continental shelf is a direct response to the wind intensity, the same being true for the direction of the movement. Northeast winds tend to form a counterclockwise gyre current within the bay, and therefore, the currents are forced to enter by the northern end and exit by the southern end. The currents are more intense in the northern end during flood tide and more intense in the southern end during ebb tide. The opposite can be observed when SE winds force the region, with clockwise currents entering by the southern end and exiting by the northern end and the inflow currents being more intense during flood tide, while outflow currents are more intense during the ebb tide. Southeast winds are supposedly more intense, exhibit higher speeds compared to NE winds and are responsible for a greater displacement of water mass. Consequently, SE winds contribute to a greater transport to the outside of the bay, especially when coinciding with neap tide. Through the analysis of residence time, 


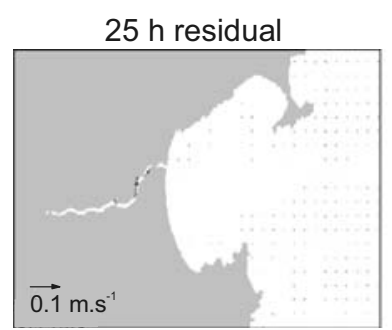

$25 \mathrm{~h}$ residual

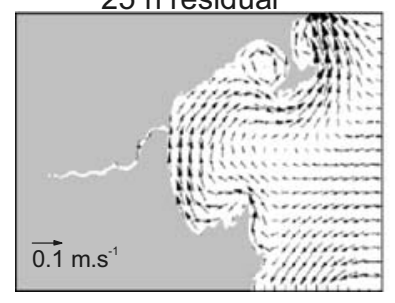

$25 \mathrm{~h}$ residual

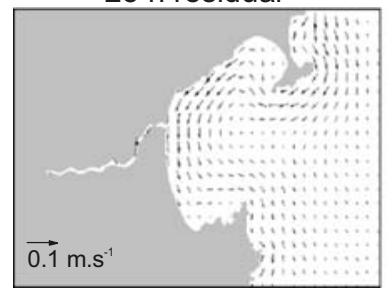

Scenario \#1

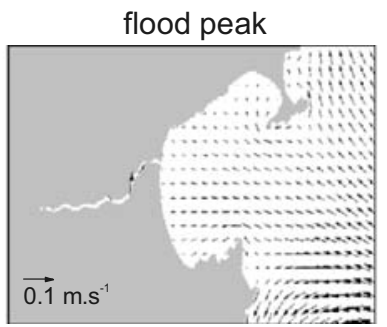

Scenario \#2

flood peak

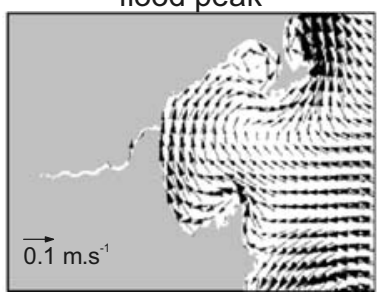

Scenario \#3 flood peak

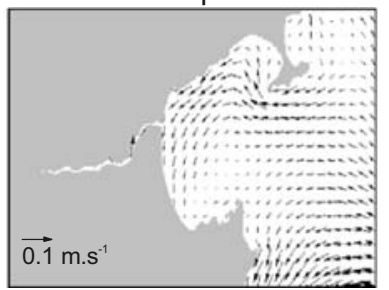

ebb peak

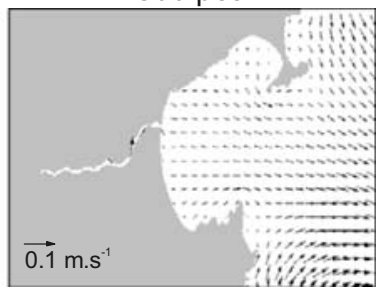

ebb peak

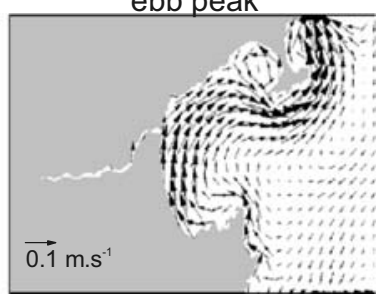

ebb peak

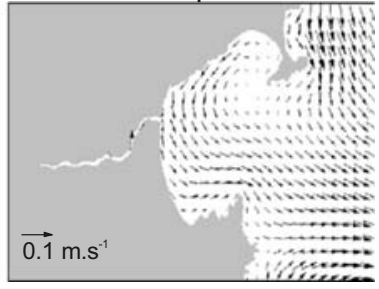

Figure 10 - 25-hours residual currents and flood and ebb peak currents for the three scenarios in neap tide. Scenario \#1: tide and river discharge; scenario \#2: tide, river discharge and wind (SE); and scenario \#3: tide, river discharge and wind (NE).

it is clear that winds are important for the transport between the bay and the adjacent continental shelf.

\section{ACKNOWLEDGEMENTS}

The authors would like to thank the Conselho Nacional de Desenvolvimento Científico e Tecnológico - CNPq for the doctoral grant awarded to MFS. CAFS is a CNPq research fellow - process No. 306772/2010-8, and the anonymous reviewers who contribute to improve the quality of the manuscript. The present study was partially funded by CNPq - process No. 483403/20075. The authors thank Professor Ramiro Neves of the Instituto Superior Técnico in Lisbon, Portugal, for welcoming MFS as a trainee.

\section{REFERENCES}

ANDREJEV 0, MYRBERG K \& LUNDBERG PA. 2004. Age and renewal time of water masses in a semi-enclosed basin - application to the Gulf of Finland. Tellus, 56A: 548-558.
ARAUJO CES, FRANCO D, MELO E \& PIMENTA F. 2003. Wave Regime Characteristics of the Southern Brazilian Coast. COPEDEC VI, 097: $15 \mathrm{pp}$.

ASP NE, BUYNEVICHI, SIEGLEE, FITZGERALDD, KLEIN AHF, CLEARY W \& ANGULO R. 2005. Coastal geomorphology of Tijucas, SC-Brazil: preliminary Holocene evolution model. In: Congresso Associação Brasileira de Estudos do Quaternário, 10., Proceedings..., 9-16 October 2005, Guarapari, Brazil: ABEQUA, p. 6-12.

BILGILI A, PROEH J, LYNCH DR, SMITH KW \& SWIFT MR. 2005. EStuary/ocean exchange and tidal mixing in a Gulf of Maine Estuary: a Lagrangian modelling study. Estuar., Coast. Shelf S., 65: 607-624.

BOLIN B \& RODHE H. 1973. A note on the concepts of age distribution and transit time in natural reservoirs. Tellus, 25: 58-62.

BOWDEN KF. 1983. Physical Oceanography of Coastal Waters. Ellis Horwood Ltd.: Chichester, UK. 302 pp.

BRAUNSCHWEIG F, MARTINS F, CHAMBEL P \& NEVES R. 2003. A methodology to estimate renewal time scales in estuaries: the Tagus estuary case. Ocean Dynamics, 53: 137-145.

BUYNEVICH I, ASP N, FITZGERALD D, CLEARY W, KLEIN AHF, 
starting simulations - day 0

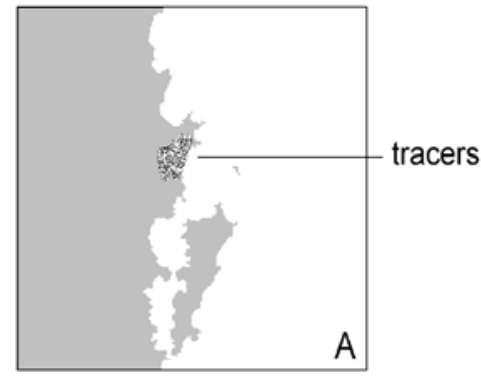

scenario 1 - day 75

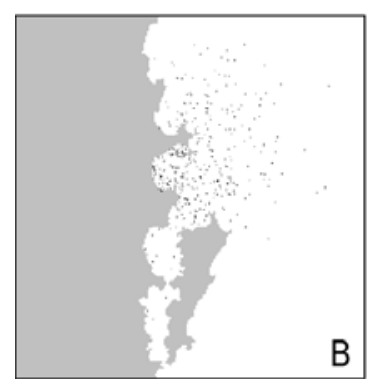

scenario 2 - day 19

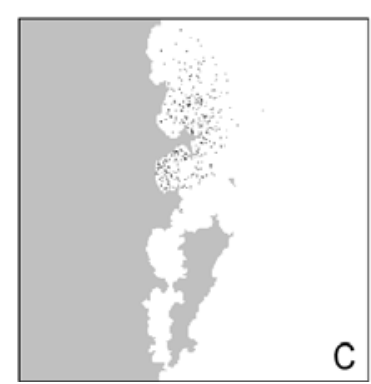

scenario 3 - day 15

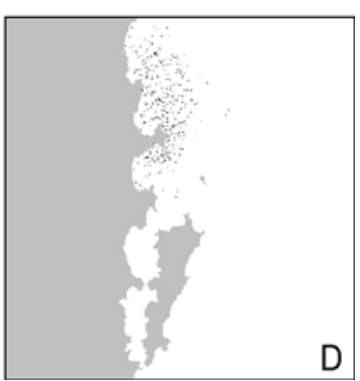

Figure 11 - Dispersion of tracers along the simulations. (A) tracers concentrates in the Tijucas Bay (B, C and D) tracers dispersed in their residence time for scenarios 1,2 and 3 .

SIEGLE E \& ANGULO R. 2005. Mud in the Surf: Nature at work in a Brazilian Bay. EOS, Transactions American Geophysical Union, 86: 301-308.

CHEN XJ. 1998. Wind-wave driven circulation on the coral reef at Bora Bay, Miyako Island. Earth and Env. Sci., 17(2): 133-143.

CHOI KW \& LEE JH. 2004. Numerical determination of flushing time on stratified water bodies. Journal of Marine Systems, 50: 263-281.

DAVIES AM. 1982. Meteorologically-induced circulation on the NorthWest European continental shelf: from a three-dimensional numerical model. Oceanologica Acta, 5: 269-280.

DAVIES AM \& JONES JE. 1992. A three-dimensional wind driven circuIation model of the Celtic and Irish seas. Continental Shelf Research, 12: 159-188.

DAVIES AM \& HALL P. 1998. The sensitivity of tidal current profiles in the North Channel of the Irish Sea to the parametrization of momentum diffusion. Continental Shelf Research, 18: 357-404.

DECASTRO M, GÓMEZ-GESTEIRA M, PREGO R \& NEVES R. 2003. Wind influence on water exchange between the ria of Ferrol (NW Spain) and the shelf. Estuar., Coast. Shelf S., 56: 1055-1064.

DELEERSNIJDERE, CAMPIN JM \& DELHEZ EJM. 2001. The concept of age in marine modelling: I. Theory and preliminary model results. J. Mar. Syst., 28: 229-267.

DYER KR. 1973. Estuaries: A Physical Introduction. John Wiley \& Sons, New York, 140 pp.
FITZGERALD DM, CLEARY WJ, BUYNEVICH IV, HEIN CJ, KLEIN AHF, ASP N \& ANGULO R. 2007. Strandplain evolution along the southern coast of Santa Catarina, Brazil. J. Coastal Res. (Proceedings of the 9th International Coastal Symposium), Special Issue, 50: 152-156.

GAPLAN. 1986. Atlas de Santa Catarina. Florianópolis, Gabinete de Planejamento, $173 \mathrm{pp}$.

GARCIA ACM. 2008. Fine Sediments resuspension processes and transport in Nazaré Submarine Canyon. Master Dissertation, PhD degree in Environmental Engineering. Instituto Superior Técnico, Universidade de Lisboa, Portugal, $150 \mathrm{pp}$.

GILLIBRAND PA. 2001. Calculating exchange times in a Scottish fjord using a two-dimensional, laterally-integrated numerical model. Estuar. Coast. Shelf S., 53: 437-449.

GOULART SVG. 1993. Dados climáticos para avaliação de desempenho térmico de edificações em Florianópolis. Master dissertation, UFSC, Santa Catarina, Brazil, 123 pp.

KOUSKY VE. 1979. Frontal Influences on Northeast Brazil. Monthly Weather Review, 107: 1140-1153.

LEGECKIS R \& GORDON AL. 1982. Satellite observations of the Brazil and Falkland currents - 1975 to 1976 and 1978. Deep-Sea Research, 29: $375-401$.

LUFF R \& POHLMANN T. 1995. Calculation of water exchange times in the ICES-boxes with an Eulerian dispersion model using a half-life time approach, Deutsche Hydr. Zeitschr., 47: 287-299. 
LYARD F, LEFEVRE F, LETELLIER T \& FRANCIS 0. 2006. Modelling the global ocean tides: modern insights from FES2004. Ocean Dynamics, 56(5-6): 394-415.

MALHADAS MS, SILVA A, LEITÃO PC \& NEVES R. 2009b. Effect of the bathymetric changes on the hydrodynamics and residence time of the Óbidos Lagoon (Portugal). J. Coast. Res., 56: 549-553.

MALHADAS MS, NEVES R, LEITÃO PC \& SILVA A. 2010. Influence of tide and waves on water renewal in Óbidos Lagoon, Portugal. Ocean Dynamics, 60: 41-55.

MIRANDA LB. 1982. Análise de massa de água de plataforma continental e da região oceânica adjacente: Cabo de São Tomé (RJ) à Ilha de São Sebastião (SP). São Paulo. Tese (Livre Docência), Instituto Oceanográfico, Universidade de São Paulo, São Paulo, Brazil, 194 pp.

MIRANDA R, BRAUNSCHWEIG F, LEITÃO P, NEVES R, MARTINS F \& SANTOS A. 2000. MOHID 2000 - a coastal integrated object-oriented model. Hydraul. Eng. Software VIII S: 405-415.

MARTINS F, NEVES R, LEITÃO P \& SILVA A. 2001. 3D modelling in the Sado estuary using a new generic coordinate approach. Oceanologica Acta, 24: S51-S62.

OLIVEIRA A \& BAPTISTA AM. 1997. Diagnostic modeling of residence times in estuaries. Water Resources Res., 33(8): 1935-1946.

OLSON DB, PODESTA G, EVANS RH \& BROWN OB. 1998. Temporal variations in the separation of Brazil and Malvinas Currents. Deep-Sea Res., 35(12): 1971-1990.

REZENDE JHM. 2003. Intrusões da Água Central do Atlântico Sul na Plataforma Continental Sudeste durante o verão. São Paulo. Doctorate thesis on Physical Oceanography, Universidade de São Paulo. 120 pp.

RODRIGUES MLG, FRANCO D \& SUGAHARA S. 2004. Climatologia de frentes frias no litoral de Santa Catarina. Brazilian Journal of Geohysics, 22(2): 135-151

SATYAMURTYP, MATTOS LF, NOBRE CA \& SILVA DIAS PL. 1998. Tropics - South America. In: KAULY DJ \& VINCENT DG (Eds.). Meteorology of the Southern Hemisphere. American Meteorological Society, Boston, 119-139.

SCHETTINI CAF. 2002. Caracterização física do estuário do rio Itajaí-Açu. Revista Brasileira de Recursos Hídricos, 7(1): 123-142.

SCHETTINI CAF \& CARVALHO JLB. 1998. Suspended sediment balance in the estuary of Itajaí-açu River during a low discharge period. Anais da Academia Brasileira de Ciências, 70: 325-334.

SCHETTINI CAF \& TOLDO EE Jr. 2006. Fine sediment transport modes in the Itajaí-Açu estuary, Southern Brazil. J. Coastal Res., 39: 515-519.
SCHETTINI CAF, CARVALHO JLB \& TRUCCOLO EC. 1999. Aspectos hidrodinâmicos da enseada da Armação do Itapocoroy, SC. Notas Téc. FACIMAR, 3: 99-109.

SCHETTINI CAF, RICKLEFS K, TRUCCOLO EC \& GOLBIG V. 2006. Synoptic hydrography of a highly stratified estuary. Ocean Dynamics, 56: $308-319$.

SCHETTINI CAF, ALMEIDA DC, SIEGLE E \& ALENCAR ACB. 2010. A snapshot of suspended sediment and fluid mud occurrence in a mixed-energy embayment, Tijucas Bay, Brazil. Geo-Mar Lett., doi: 10.1007/s00367-009-0153-8.

SIGNELL RP \& BUTMAN B. 1992. Modelling tidal exchange and dispersion in Boston Harbour. Journal of Geophysical Research - Oceans, 97(C10): 15591-15606.

STECH JL \& LORENZZETTI JA. 1992. The response of the South Brazil Bight to the passage of wintertime cold fronts. Journal of Geophysical Research, 97(C6): 9507-9520.

SUZUKIT \& MATSUYAMA M. 2000. Numerical experiments on stratified wind-induced circulation in Tokyo Bay, Japan. Estuar., Coast. Shelf S., 50: $17-25$.

TAKEOKA H. 1984. Fundamental concepts of exchange and transport time scales in a coastal sea. Continental Shelf Res., 3: 311-326.

TARTINVILLE B, DELEERSNIJDER E \& RANCHER J. 1997. The water residence time in the Mururoa atoll lagoon: sensitivity analysis of a three-dimensional model. Coral Reefs, 16: 193-203.

TRUCCOLO EC. 2011. Assessment of the wind behavior in the northern coast of Santa Catarina. Rev. Bras. Meteorol., 26(3): 451-460.

TRUCCOLO EC, FRANCO D \& SCHETTINI CAF. 2006. The low frequency sea level oscillations in the northern coast of Santa Catarina, Brazil. J. Coastal Res., 39: 547-552.

WANG CF, HSU MH \& KUO AY. 2004. Residence time of the Danshuei River estuary, Taiwan. Estuar., Coast. Shelf S., 60: 381-393.

WILLMOTT CJ, ACKLESON SG, DAVIS RE, FEDDEMA JJ, KLINK KM, LEGATES DR, O'DONNELL J \& ROWE CM. 1985. Statistics for the evaluation and comparison of models. Journal of Geophysical Research, 90(C5): 8995-9005.

XIE L \& EGGLESTON CB. 1999. Computer simulation of wind induced estuarine circulation patterns and estuary shelf exchange processes: The potencial role of wind forcing on larval transport. Estuar., Coast. Shelf S., 49: 221-234.

ZIMMERMAN JTF. 1976. Mixing and flushing of tidal embayments in the western Dutch Wadden Sea, part I. Distribution of salinity and calculation of mixing time scales. Netherlands, J. Sea Res., 10(2): 149-191. 


\section{NOTES ABOUT THE AUTHORS}

Márcio Fabiano de Souza. Bachelor in Oceanography by the Universidade do Vale do Itajai (2000), Master in Science in Aquaculture by the Universidade Federal de Santa Catarina (2005) and Doctorate in Geosciences by the Universidade Federal do Rio Grande do Sul (2010). Main interests are in marine geology with an emphasis in sediment dynamics studies using numerical modeling, as well as coastal hydrodynamics.

Carlos Augusto França Schettini. Bachelor in Oceanography by the Fundação Universidade Federal do Rio Grande (1991), Master in Science by the Universidade Federal Fluminense (1994) and Doctorate in Geosciences by the Universidade Federal do Rio Grande do Sul (UFRGS, 2001). Lecturer and scientist in the Universidade do Vale do Itajai entre 1994 e 2009. Collaborator lecturer in the Graduate Program in Geosciences of UFRGS since 2006. Assistant Professor of the Instituto de Ciências do Mar of the Universidade Federal do Ceará (LABOMAR-UFC) between 2009 and 2010. Full Professor in Oceanography in the Departament of Oceanography of the Universidade Federal de Pernambuco. Main interests are coastal hydrodynamics and transport processes in estuaries and adjacent coastal waters. His interests also has interest in interdisciplinary studies embracing watersheds and continental shelves, looking for the conceptualization of the mass transfer in the continent-ocean interface. 